\title{
A SURVEY ON IONIC AND METABOLITE FACTORS OF BLOOD SERUM IN KUTUM (RUTILUS FRISII KUTUM)
}

\author{
Majid AFKHAMI *, Kazem Darvish BASTAMI **, \\ Nariman SHABANI *** and Farzane SOLTANI ****
}

* Islamic Azad University, Yung Researches Club, Bandar Abbas Branch, Bandar Abbas, Iran, P. O. Box 79159-1311, m_afkhami82@yahoo.com, darvish_60@yahoo.com, soltanif@yahoo.com

** Gorgan University of Agricultural Sciences and Natural Resources, Fisheries Faculty, P. O. Box 45165-386, Gorgan, Iran, nshabani@yahoo.com

DOI: 10.1515/trser-2015-0021

KEYWORDS: Kutum (Rutilus frisii kutum), plasma serum, ionic and non-ionic components.

\section{ABSTRACT}

In this study, ionic parameters and metabolite factors (cholesterol, total protein, and glucose) of serum and their interrelationships were detected in 48 specimens of kutum (Rutilus frisii kutum) captured during spawning migration. Blood sampling was conducted by cutting the caudal peduncle of each sample, and blood was collected into heparinized and sterile capillary glass tubes.

Results indicated that values of $\mathrm{Na}^{+}, \mathrm{Ca}^{+2}, \mathrm{~K}^{+}$, and $\mathrm{Mg}^{+2}$ revealed the highest to the lowest content in blood serum of kutum, respectively. Cholesterol concentration was higher than glucose and the latter was estimated more than total protein. $\mathrm{Na}^{+}$was positively correlated with $\mathrm{Mg}^{+2}(\mathrm{P}<0.01)$, whereas it shows reversed correlations with glucose $(\mathrm{P}<0.01)$ and $\mathrm{pH}$ $(\mathrm{P}<0.05)$. The results deduced in the present trail, might improve reproductive and farming management of this valuable species.

ZUSAMMENFASSUNG: Untersuchungen zu ionischen und Stoffwechselfaktoren des Blutserums von Kutum-Plötze (Rutilus frisii kutum).

In dieser Studie werden die ionischen Parameter und Metabolismus Faktoren (Cholesterol, Gesamteiweißstoffe und Glukose) des Serums und ihre Wechselbeziehungen zueinander in 48 Exemplaren der Kutum-Plötze (Rutilus frisii kutum) untersucht, wobei die Individuen während der Laichmigration gefangen wurden. Aus dem abgeschnittenen Stammteil des Schwanzes wurden Blutproben entnommen und in sterilen, heparinisierten Kapillaren-Glasröhrchen gesammelt.

Die Ergebnisse zeigten jeweils von den höchsten zu den niedrigsten Werten Anteile von $\mathrm{Na}^{+}, \mathrm{Ca}^{+2}, \mathrm{~K}^{+}$und $\mathrm{Mg}^{+2}$ im Blutserum von Kutum. Die Konzentration von Cholesterol war höher als jene von Glukose und letztere wurde mit einem Wert von mehr als das Gesamtprotein geschätzt. $\mathrm{Na}^{+}$war positiv korreliert mit $\mathrm{Mg}^{+2}(\mathrm{P}<0.01)$, während es eine umgekehrte Beziehung zu Glukose $(\mathrm{P}<0.01)$ und $\mathrm{pH}(\mathrm{P}<0.05)$ zeigte. Die auf dem gegenwärtigwen Weg abgeleiteten Ergebnisse können das Reproduktions- und Züchtungsmanagement dieser wertvollen Art verbessern. 
REZUMAT: Studiul influenței unor factori ionici și metabolici asupra serului sângelui la specia Rutilus frisii kutum.

În acest studiu, au fost urmăriți, la 48 de invidizi din specia Rutilus frisii kutum, capturați în timpul migrației pentru depunerea pontei, parametri ionici și factorii metabolici (colesterol, proteine totale și glucoza) din serul sanguin și relațiile dintre aceștia. Probele de sânge au fost luate prin tăierea pedunculului caudal de la fiecare individ, sângele a fost colectat în tubușoare de sticlă capilare, sterile și cu conținut de heparină.

Rezultatele arată că valorile $\mathrm{Na}^{+}, \mathrm{Ca}^{+2}, \mathrm{~K}^{+}$și $\mathrm{Mg}^{+2}$ variază în serul sanguin al speciei Rutilus frisii kutum. Concentrația de colesterol este mai mare decât cea de glucoză, iar aceasta din urmă a fost estimată ca fiind mai mare decât proteina totală. $\mathrm{Na}^{+}$a fost corelat pozitiv cu $\operatorname{Mg}^{+2}(\mathrm{P}<0,01)$, în timp ce se identifică corelații inverse cu glucoza $(\mathrm{P}<0,01)$ și cu pH-ul $(\mathrm{P}<$ $0,05)$. Rezultatele obținute ar putea îmbunătăţi managementul reproductiv și de creștere a acestei specii.

\section{INTRODUCTION}

Kutum (Rutilus frisii kutum Kamenskii 1901) lives in the Caspian Sea. This species is a migratory anadromous fish spawning in rivers during March and April. It has a group synchronous single spawning behaviour (Sharyati, 1993), spawning on aquatic weeds, gravel, and sandy substrates in rivers and lagoons (Abdoli, 1999).

This fish is the most popular food fish in southern coastal region of the Caspian Sea in the north of Iran, where it is locally known as Mahisefid (meaning white fish) because of its shiny scales. It has a great economic importance for the Iranian fishing industry in the southern Caspian Sea with more than $900 \mathrm{~km}$ of coastline. There is a little information about blood characteristics in Kutum ( $R$. frisii kutum). Such information would provide a better understanding of the life history and physiological mechanisms of this species, especially when they are released into the southern area of the Caspian Sea for restocking. Determination of these parameters also may be useful in assessing any changes in water quality, related to soil quality, and fish response as well (Bastami et al., 2010).

\section{MATERIAL AND METHODS}

Kutums ( $R$. frisii kutum) were captured from the estuary of Tajan River in Sari inlets to the Caspian Sea during migration in 2010. The average weight and length of fish sampled were $977 \pm 229 \mathrm{~g}$ and $49.62 \pm 1.2 \mathrm{~cm}$, respectively.

\section{Blood sampling procedure}

Blood sampling was conducted by cutting the caudal peduncle of each sample, and blood was collected into heparinized and sterile capillary glass tubes. For blood plasma assessment, tubes were centrifuged for five minutes at 3,000 rpm. Then, the tubes were broken, and the resultant blood plasma was emptied into sterile micro tubes for further analysis.

Blood and seminal biochemical parameters, including $\mathrm{Mg}^{2+}, \mathrm{Ca}^{2+}$, total protein, cholesterol, and glucose contents, were calculated by spectrophotometry with a WPA-S2000 spectrophotometer and standard kits (Pars Co.). $\mathrm{K}^{+}$and $\mathrm{Na}^{+}$were analyzed using JENWAY-PF $\mathrm{P7}$ Electrolyte Analyzer. The $\mathrm{pH}$ of blood plasma was measured with a classical laboratory $\mathrm{pH}$ meter (Orion Model 410A pH meter).

\section{Statistical analysis}

Analysis of each parameter was replicated three times. Means of blood biochemical parameters were subjected to homogeneity of variance and one-way ANOVA using SPSS program (version 13). Pearson's coefficient was used for linear correlation ( $r$ ) between variables at $\mathrm{P}<0.05$. 


\section{RESULTS AND DISCUSSION}

According to the results presented in table number 1 , the values of $\mathrm{Na}^{+}, \mathrm{Ca}^{+2}, \mathrm{~K}^{+}$, and $\mathrm{Mg}^{+2}$ showed the highest to the lowest content in blood plasma of kutum, respectively. Cholesterol content was higher than glucose and the latter was estimated more than total protein. As shown in table number 2, representing the relationships among studied factors in serum, $\mathrm{Na}^{+}$was positively correlated with $\mathrm{Mg}^{+2}(\mathrm{P}<0.01)$, but there was reverse relationship between $\mathrm{Na}^{+}$with glucose $(\mathrm{P}<0.01)$ and $\mathrm{pH}(\mathrm{P}<0.05)$.

Table 1: Biochemical component (mean \pm standard deviation) and range in blood plasma measured in broodstocks of kutum $(n=48)$.

\begin{tabular}{|l|l|l|}
\hline Parameter & Mean \pm standard deviation & \multicolumn{1}{|c|}{ Range } \\
\hline $\mathrm{Na}^{+}(\mathrm{mmol} / \mathrm{l})$ & $180.07 \pm 21.46$ & $151-210.2$ \\
$\mathrm{~K}^{+}(\mathrm{mmol} / \mathrm{l})$ & $3.2 \pm 2.41$ & $1.14-7.79$ \\
$\mathrm{Ca}^{+2}(\mathrm{mmol} / \mathrm{l})$ & $3.6 \pm 0.3$ & $3-4.1$ \\
$\mathrm{Mg}^{+2}(\mathrm{mmol} / \mathrm{l})$ & $1.75 \pm 0.6$ & $0.9-3$ \\
Cholesterol $(\mathrm{mg} / \mathrm{l})$ & $1882.18 \pm 643.16$ & $22.73-105.4$ \\
Total Protein $(\mathrm{mg} / \mathrm{l})$ & $44.13 \pm 18.72$ & $19-105.4$ \\
Glucose $(\mathrm{mg} / \mathrm{l})$ & $1266.67 \pm 647.09$ & $414.4-2857.8$ \\
$\mathrm{pH}$ & $7.61 \pm 0.4$ & 6.89 \\
\hline
\end{tabular}

Significant positive correlation $(\mathrm{P}<0.05)$ is between calcium concentration and total protein content. $\mathrm{Mg}^{+}$had a significant and positive relationship with the ratio of $\mathrm{Na}^{+}$to $\mathrm{K}^{+}$and $\mathrm{Ca}^{+2}$ to $\mathrm{K}^{+}$ratio $(\mathrm{P}<0.05)$ while it revealed a reversed correlation with $\mathrm{pH}(\mathrm{P}<0.01)$ and glucose $(\mathrm{P}<0.05) . \mathrm{Ca}^{+2}$ concentration correlated positively with total protein $(\mathrm{P}<0.05)$. The correlation between the ratio of $\mathrm{Na}^{+}$to $\mathrm{K}^{+}$and $\mathrm{Ca}^{+2}$ to $\mathrm{K}^{+}$ratio was positive $(\mathrm{P}<0.01)$.

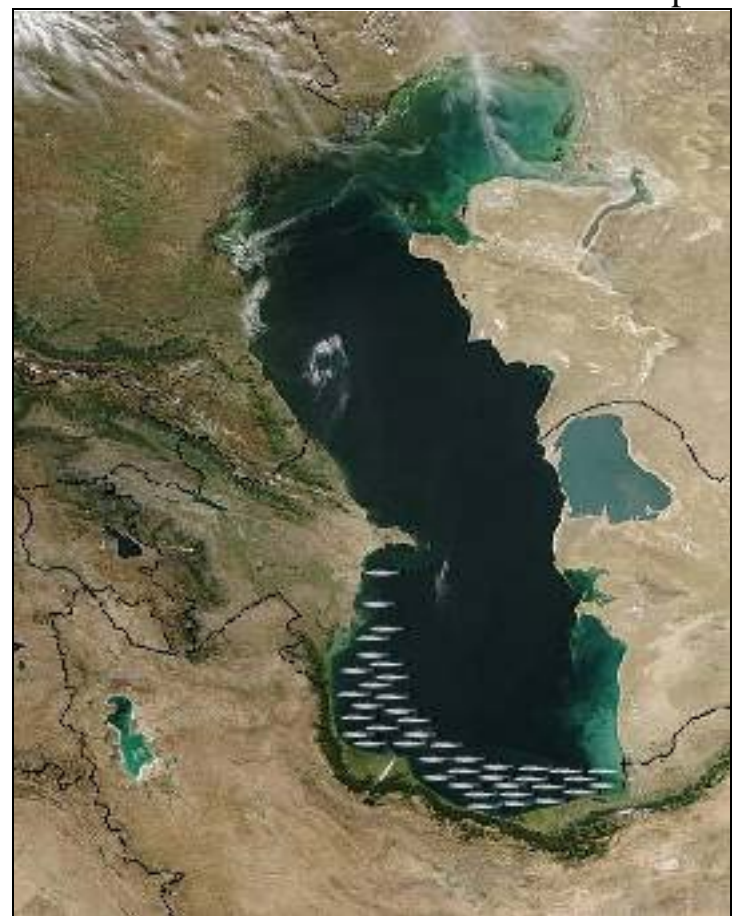

Figure 1: The Caspian Sea and distribution of kutum (Rutilus frisii kutum). 
The first connective tissues between fish and its surrounding environment operating in gas transportation, acid-alkaline balance, ion regulation, and ammonia excretion are the gills. Environmental stressors are of important factors confining fish condition under any rearing situation.

Fish migration from saltwater to freshwater (like studied kutum species here) makes changes in ionic and acid-alkaline balances which influences on physiology and growth. It was found that the values of $\mathrm{Na}^{+}, \mathrm{Ca}^{+2}, \mathrm{~K}^{+}$, and $\mathrm{Mg}^{+2}$ ions displayed the highest to the lowest content in blood plasma of kutum, respectively, which is in accordance with findings of Sattari (2002) (Tab. 1). Moreover, cholesterol content was higher than glucose and the latter was measured more than total protein which was previously evidenced by Luz et al. (2008). Thrall et al. (2004) estimated the natural content of calcium in fish species for $20 \mathrm{mg} / \mathrm{dl}$. Majabi et al. (2001) found two effective variables of fish species and environment condition on sodium concentration and appraised it for approximately $150 \mathrm{~m} \mathrm{~mol} / \mathrm{l}$ in most fishes. They also identified $\mathrm{Na}^{+}$and $\mathrm{Cl}^{-}$deficiency as a result of general infections and functional disorders in gills.

Table 2: Correlation between ionic and non-ionic factors of blood plasma in migrating broodstocks of kutum ( $\mathrm{n}=48)$; (T. p. - total protein, Ch. - cholesterol, Gl. - glucose).

\begin{tabular}{|l|c|c|c|c|c|c|c|c|c|}
\hline & $\mathrm{Na}^{+}$ & $\mathrm{K}^{+}$ & $\mathrm{Ca}^{+2}$ & $\mathrm{Mg}^{+2}$ & $\mathrm{Na}^{+} / \mathrm{K}^{+}$ & $\mathrm{K}^{+} / \mathrm{Ca}^{+2}$ & T. p. & Ch. & Gl. \\
\hline $\mathrm{K}^{+}$ & -0.081 & & & & & & & & \\
\hline $\mathrm{Ca}^{+2}$ & -0.176 & 0.01 & & & & & & & \\
\hline $\mathrm{Mg}^{+2}$ & $0.776^{\mathrm{b}}$ & -0.272 & 0.15 & & & & & & \\
\hline $\mathrm{Na}^{+} / \mathrm{K}^{+}$ & 0.424 & -0.635 & -0.085 & $0.544^{\mathrm{a}}$ & & & & & \\
\hline $\mathrm{K}^{+} / \mathrm{Ca}^{+2}$ & 0.226 & $-0.87^{\mathrm{b}}$ & 0.042 & $0.554^{\mathrm{a}}$ & 0.818 & & & & \\
\hline T. p. & 0.138 & 0.137 & $0.515^{\mathrm{a}}$ & -0.109 & -0.23 & -0.081 & & & \\
\hline Ch. & 0.05 & 0.066 & 0.078 & 0.085 & -0.035 & 0.092 & 0.366 & & \\
\hline Gl. & -0.698 & -0.045 & 0.258 & -0.591 & -0.285 & -0.082 & 0.412 & 0.055 & \\
\hline $\mathrm{pH}$ & -0.629 & -0.158 & -0.26 & -0.753 & -0.327 & -0.384 & -0.149 & -0.258 & 0.226 \\
\hline
\end{tabular}

a Shows significant difference $(\mathrm{P}<0.05)$

b Shows significant difference $(\mathrm{P}<0.01)$

Thrall et al. (2004) reported $\mathrm{Na}^{+}$and $\mathrm{K}^{+}$concentrations of 150 and three mmol/l, respectively, in freshwater fish which is in agreement with the present study. Wurts and Durborow (1992) deduced $\mathrm{Ca}^{+2}$ and $\mathrm{Mg}^{+2}$ ions as necessary factors in blood biological processes. Fish can directly access to $\mathrm{Ca}^{+2}$ and $\mathrm{Mg}^{+2}$ ions from water and food. So, $\mathrm{Ca}^{+2}$ acts as one of the most important ions in fish culture water. They also recommended a range of 25 to $100 \mathrm{mg} / \mathrm{l}$ for $\mathrm{Ca}^{+2}$ concentration and commented that high capacity of calcium is needed for culturing striped bass while rainbow trout can tolerate $\mathrm{Ca}^{+2}$ concentration of $10 \mathrm{mg} / \mathrm{l}$ when $\mathrm{pH}$ is adjusted upper than 6.5 .

$\mathrm{Ca}^{+2}$ content of blood plasma in female broodstocks is considered as a desirable index to properly evaluate the time of sexual ripening in broodstocks, since its concentration gradually rise up during several months before reproductive season until a peak immediately one or two months before the beginning of reproductive season. Afterwards, during the reproductive season, its content rather decreases. This was attributed to the reproductive cycle and crucial importance of calcium during vitellogenesis stage. For example, its content was discovered to be 4.5 and $2.8 \mathrm{~m} \mathrm{~mol} / \mathrm{l}$ before and after reproductive season, respectively, in blood plasma of Atlantic flatfish. 
Concerning these points and coincidence of the present study with the period of maximum spawning of kutum (i.e. early spring), it might be concluded that calcium content in this trial $(3.6 \mathrm{mmol} / \mathrm{l})$ was determined after an increasing period in blood plasma of the female broodstocks followed by a decline period. There was a significant and positive correlation between calcium content and total protein. This might be attributed to two reasons. Firstly, gonad development with fluctuations in calcium level in blood plasma occurs simultaneously with fish growth and increasing in size and subsequently increased total protein.

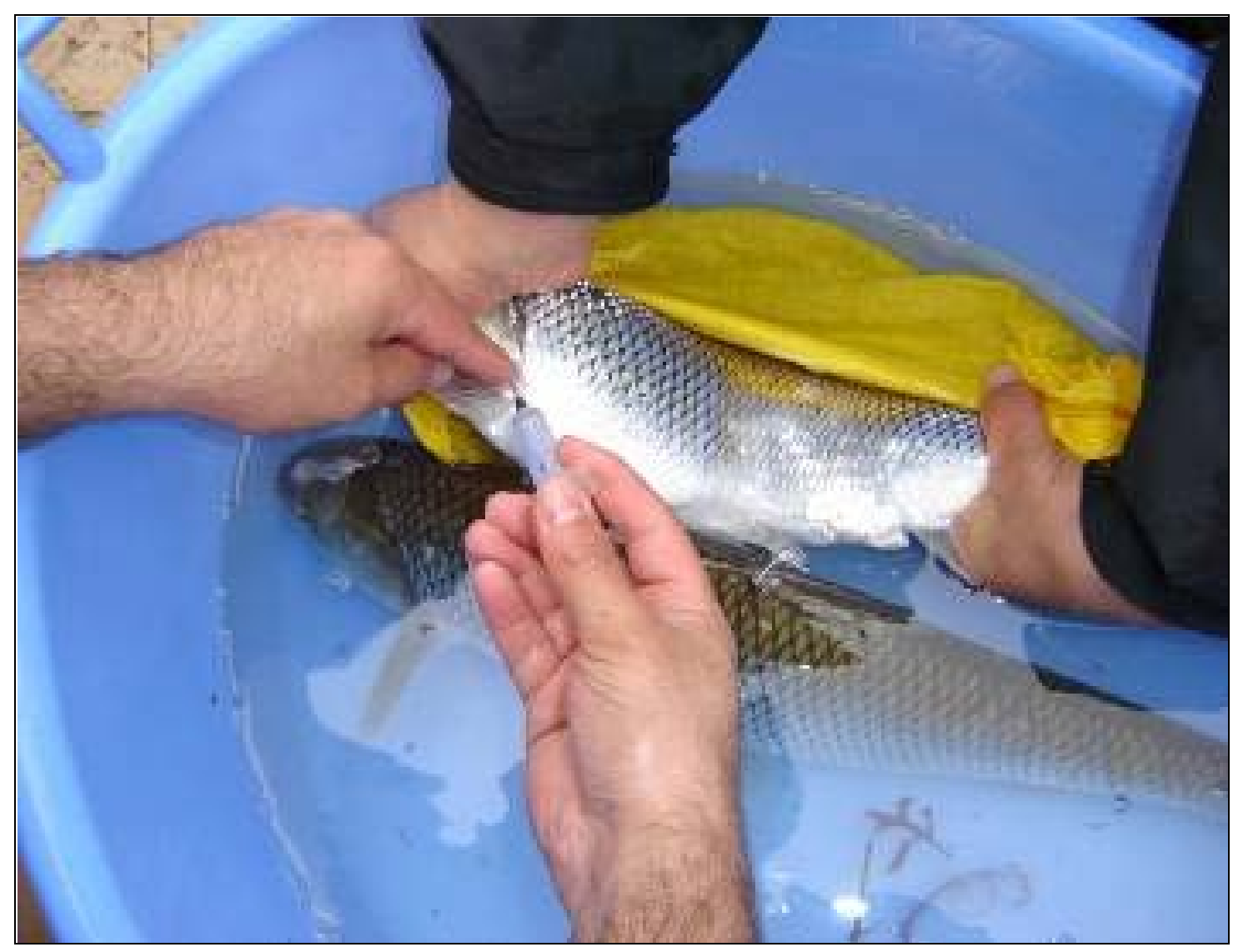

Figure 2: Blood sampling from kutum (Rutilus frisii kutum) broodstock.

Direct relationship between these factors is explicable since the present experiment was conducted during maximum spawning period of kutum (increasing concentration of calcium in plasma).

Secondly, calcium contributes in protein metabolism and acts as a cofactor in relation to many metabolic and enzymatic reactions. With regard to the enzymatic apparatus of $\mathrm{Na}^{+-} \mathrm{K}^{+}$ ATPas and the results presented in table number 2, the significant and reverse relationship between $\mathrm{K}$ and the ratio of $\mathrm{Na}^{+}$to $\mathrm{K}^{+}$is remarkable. This relation might be evident at first glimpse, but the functional concept of $\mathrm{Na}^{+-} \mathrm{K}^{+}$ATPase enzymatic apparatus could be perceived if attentively be noticed. The reversed relationship mentioned above, actually implied to the reversed path of $\mathrm{K}^{+}$and $\mathrm{Na}^{+}$ions in the aforesaid enzymatic apparatus. There was a significant correlation between $\mathrm{Mg}^{+2}$ and $\mathrm{Na}^{+}$in this trail. 
Davis et al. (2005) stated that the presence of $\mathrm{Mg}^{+2}$ in culture water aids to the loss of other salts (like $\mathrm{Na}^{+}$and $\mathrm{K}^{+}$) from fish body fluid (for instance blood) which is in agreement with the results indicated in this survey. Indeed, the significant and direct relationship between $\mathrm{Mg}^{+2}$ and the ratio of $\mathrm{Na}^{+}$to $\mathrm{K}^{+}$implies the significant correlation between $\mathrm{Na}^{+}$and $\mathrm{Mg}^{+2}$.

\section{REFERENCES}

1. Davis D. A., Saoud I. P., Boyd C. E. and Rouse D. B., 2005 - Effects of potassium, magnesium, and age on growth and survival of Litopenaeus vannamei post-larvae reared in inland low salinity well waters in west Alabama, Journal of the World Aquaculture Society, 36, 403-406.

2. Luz R. K., Martínez-Álvarez R. M., De Pedro N. and Delgado M. J., 2008 - Growth, food intake regulation and metabolic adaptations in goldfish (Carassius auratus) exposed to different salinities, Aquaculture, 276, 171-178.

3. Majabi A., Nazifi S. and Safi S. H., 2001 - Veterinary biochemistry, Norbakhsh, Tehran, 390. (in Persian)

4. Sattari M., 2002 - Ichtiology (1): anatomy and physiology, Naghsh-e Mehr, Tehran, 659. (in Persian)

5. Sharyati A., 1993 - Fishes of the Caspian Sea region, Iranian Fisheries Company, Iran, 77-79. (in Persian)

6. Thrall M. A., Baker D. C., Campbell T. W., Denicola D., Fettman M. J., Lassen E. D., Rebar A. and Weiser G., 2004 - Veterinary haematology and clinical chemistry, Lippincott Williams and Wikins, Baltimore, 501.

7. Wurts W. A. and Durborow R. M., 1992 - Interactions of pH, carbon dioxide, alkalinity and hardness in fish ponds, SRAC Publication, 464. 